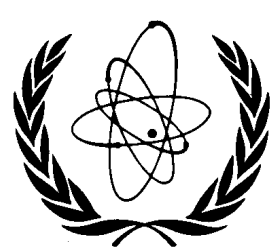

International Atomic Energy Agency INFORMATION CIRCULAR
INFCIRC/546

24 December 1997

GENERAL Distr.

Original: ARABIC, CHINESE

ENGLISH, FRENCH, RUSSIAN and SPANISH

\title{
JOINT CONVENTION ON THE SAFETY OF SPENT FUEL MANAGEMENT AND ON THE SAFETY OF RADIOACTIVE WASTE MANAGEMENT
}

\section{Latest Status}

1. The Joint Convention on the Safety of Spent Fuel Management and on the Safety of Radioactive Waste Management was adopted on 5 September 1997 by a Diplomatic Conference convened by the International Atomic Energy Agency at its headquarters from 1 to 5 September 1997. The Joint Convention was opened for signature at Vienna on 29 September 1997 during the forty-first session of the General Conference of the International Atomic Energy Agency and will remain open for signature until its entry into force.

2. Pursuant to article 40, the Joint Convention will enter into force on the ninetieth day after the date of deposit with the Depositary of the twenty-fifth instrument of ratification, acceptance or approval, including the instruments of fifteen States each having an operational nuclear power plant.

3. The text of the Convention, as adopted, is attached hereto for the information of Member States. 


\section{JOINT CONVENTION}

ON THE SAFETY OF SPENT FUEL MANAGEMENT AND ON THE SAFETY OF RADIOACTIVE WASTE MANAGEMENT 


\section{JOINT CONVENTION \\ ON THE SAFETY OF SPENT FUEL MANAGEMENT AND \\ ON THE SAFETY OF RADIOACTIVE WASTE MANAGEMENT}

PREAMBLE

CHAPTER 1 OBJECTIVES, DEFINITIONS AND SCOPE OF APPLICATION

ARTICLE 1 OBJECTIVES

ARTICLE 2 DEFINITIONS

ARTICLE 3 SCOPE OF APPLICATION

CHAPTER 2 SAFETY OF SPENT FUEL MANAGEMENT

ARTICLE 4 GENERAL SAFETY REQUIREMENTS

ARTICLE 5 EXISTING FACILITIES

ARTICLE 6 SITING OF PROPOSED FACILITIES

ARTICLE 7 DESIGN AND CONSTRUCTION OF FACILITIES

ARTICLE 8 ASSESSMENT OF SAFETY OF FACILITIES

ARTICLE 9 OPERATION OF FACILITIES

ARTICLE 10 DISPOSAL OF SPENT FUEL

CHAPTER 3 SAFETY OF RADIOACTIVE WASTE MANAGEMENT

ARTICLE 11 GENERAL SAFETY REQUIREMENTS

ARTICLE 12 EXISTING FACILITIES AND PAST PRACTICES

ARTICLE 13 SITING OF PROPOSED FACILITIES

ARTICLE 14 DESIGN AND CONSTRUCTION OF FACILITIES

ARTICLE 15 ASSESSMENT OF SAFETY OF FACILITIES

ARTICLE 16 OPERATION OF FACILITIES

ARTICLE 17 INSTITUTIONAL MEASURES AFTER CLOSURE

CHAPTER 4 GENERAL SAFETY PROVISIONS

ARTICLE 18 IMPLEMENTING MEASURES

ARTICLE 19 LEGISLATIVE AND REGULATORY FRAMEWORK

ARTICLE 20 REGULATORY BODY

ARTICLE 21 RESPONSIBILITY OF THE LICENCE HOLDER

ARTICLE 22 HUMAN AND FINANCIAL RESOURCES

ARTICLE 23 QUALITY ASSURANCE

ARTICLE 24 OPERATIONAL RADIATION PROTECTION

ARTICLE 25 EMERGENCY PREPAREDNESS

ARTICLE 26 DECOMMISSIONING

CHAPTER 5 MISCELLANEOUS PROVISIONS

ARTICLE 27 TRANSBOUNDARY MOVEMENT

ARTICLE 28 DISUSED SEALED SOURCES 
CHAPTER 6 MEETINGS OF THE CONTRACTING PARTIES

ARTICLE 29 PREPARATORY MEETING

ARTICLE 30 REVIEW MEETINGS

ARTICLE 31 EXTRAORDINARY MEETINGS

ARTICLE 32 REPORTING

ARTICLE 33 ATTENDANCE

ARTICLE 34 SUMMARY REPORTS

ARTICLE 35 LANGUAGES

ARTICLE 36 CONFIDENTIALITY

ARTICLE 37 SECRETARIAT

CHAPTER 7 FINAL CLAUSES AND OTHER PROVISIONS

ARTICLE 38 RESOLUTION OF DISAGREEMENTS

ARTICLE 39 SIGNATURE, RATIFICATION, ACCEPTANCE, APPROVAL, ACCESSION

ARTICLE 40 ENTRY INTO FORCE

ARTICLE 41 AMENDMENTS TO THE CONVENTION

ARTICLE 42 DENUNCIATION

ARTICLE 43 DEPOSITARY

ARTICLE 44 AUTHENTIC TEXTS 


\section{PREAMBLE}

The Contracting Parties

(i) Recognizing that the operation of nuclear reactors generates spent fuel and radioactive waste and that other applications of nuclear technologies also generate radioactive waste;

(ii) Recognizing that the same safety objectives apply both to spent fuel and radioactive waste management;

(iii) Reaffirming the importance to the international community of ensuring that sound practices are planned and implemented for the safety of spent fuel and radioactive waste management;

(iv) Recognizing the importance of informing the public on issues regarding the safety of spent fuel and radioactive waste management;

(v) Desiring to promote an effective nuclear safety culture worldwide;

(vi) Reaffirming that the ultimate responsibility for ensuring the safety of spent fuel and radioactive waste management rests with the State;

(vii) Recognizing that the definition of a fuel cycle policy rests with the State, some States considering spent fuel as a valuable resource that may be reprocessed, others electing to dispose of it;

(viii) Recognizing that spent fuel and radioactive waste excluded from the present Convention because they are within military or defence programmes should be managed in accordance with the objectives stated in this Convention; 
(ix) Affirming the importance of international co-operation in enhancing the safety of spent fuel and radioactive waste management through bilateral and multilateral mechanisms, and through this incentive Convention;

(x) Mindful of the needs of developing countries, and in particular the least developed countries, and of States with economies in transition and of the need to facilitate existing mechanisms to assist in the fulfillment of their rights and obligations set out in this incentive Convention;

(xi) Convinced that radioactive waste should, as far as is compatible with the safety of the management of such material, be disposed of in the State in which it was generated, whilst recognizing that, in certain circumstances, safe and efficient management of spent fuel and radioactive waste might be fostered through agreements among Contracting Parties to use facilities in one of them for the benefit of the other Parties, particularly where waste originates from joint projects;

(xii) Recognizing that any State has the right to ban import into its territory of foreign spent fuel and radioactive waste;

(xiii) Keeping in mind the Convention on Nuclear Safety (1994), the Convention on Early Notification of a Nuclear Accident (1986), the Convention on Assistance in the Case of a Nuclear Accident or Radiological Emergency (1986), the Convention on the Physical Protection of Nuclear Material (1980), the Convention on the Prevention of Marine Pollution by Dumping of Wastes and Other Matter as amended (1994) and other relevant international instruments;

(xiv) Keeping in mind the principles contained in the interagency "International Basic Safety Standards for Protection against Ionizing Radiation and for the Safety of Radiation Sources" (1996), in the IAEA Safety Fundamentals entitled "The Principles of Radioactive Waste Management" (1995), and in the existing international standards relating to the safety of the transport of radioactive materials; 
(xv) Recalling Chapter 22 of Agenda 21 by the United Nations Conference on Environment and Development in Rio de Janeiro adopted in 1992, which reaffirms the paramount importance of the safe and environmentally sound management of radioactive waste;

(xvi) Recognizing the desirability of strengthening the international control system applying specifically to radioactive materials as referred to in Article 1(3) of the Basel Convention on the Control of Transboundary Movements of Hazardous Wastes and Their Disposal (1989);

Have agreed as follows: 


\section{CHAPTER 1. OBJECTIVES, DEFINITIONS AND SCOPE OF APPLICATION}

\section{ARTICLE 1. OBJECTIVES}

The objectives of this Convention are:

(i) to achieve and maintain a high level of safety worldwide in spent fuel and radioactive waste management, through the enhancement of national measures and international co-operation, including where appropriate, safety-related technical co-operation;

(ii) to ensure that during all stages of spent fuel and radioactive waste management there are effective defenses against potential hazards so that individuals, society and the environment are protected from harmful effects of ionizing radiation, now and in the future, in such a way that the needs and aspirations of the present generation are met without compromising the ability of future generations to meet their needs and aspirations;

(iii) to prevent accidents with radiological consequences and to mitigate their consequences should they occur during any stage of spent fuel or radioactive waste management.

\section{ARTICLE 2. DEFINITIONS}

For the purposes of this Convention:

(a) "closure" means the completion of all operations at some time after the emplacement of spent fuel or radioactive waste in a disposal facility. This includes the final engineering or other work required to bring the facility to a condition that will be safe in the long term; 
(b) "decommissioning" means all steps leading to the release of a nuclear facility, other than a disposal facility, from regulatory control. These steps include the processes of decontamination and dismantling;

(c) "discharges" means planned and controlled releases into the environment, as a legitimate practice, within limits authorized by the regulatory body, of liquid or gaseous radioactive materials that originate from regulated nuclear facilities during normal operation;

(d) "disposal" means the emplacement of spent fuel or radioactive waste in an appropriate facility without the intention of retrieval;

(e) "licence" means any authorization, permission or certification granted by a regulatory body to carry out any activity related to management of spent fuel or of radioactive waste;

(f) "nuclear facility" means a civilian facility and its associated land, buildings and equipment in which radioactive materials are produced, processed, used, handled, stored or disposed of on such a scale that consideration of safety is required;

(g) "operating lifetime" means the period during which a spent fuel or a radioactive waste management facility is used for its intended purpose. In the case of a disposal facility, the period begins when spent fuel or radioactive waste is first emplaced in the facility and ends upon closure of the facility;

(h) "radioactive waste" means radioactive material in gaseous, liquid or solid form for which no further use is foreseen by the Contracting Party or by a natural or legal person whose decision is accepted by the Contracting Party, and which is controlled as radioactive waste by a regulatory body under the legislative and regulatory framework of the Contracting Party;

(i) "radioactive waste management" means all activities, including decommissioning activities, that relate to the handling, pretreatment, treatment, conditioning, storage, or disposal of 
radioactive waste, excluding off-site transportation. It may also involve discharges;

(j) "radioactive waste management facility" means any facility or installation the primary purpose of which is radioactive waste management, including a nuclear facility in the process of being decommissioned only if it is designated by the Contracting Party as a radioactive waste management facility;

(k) "regulatory body" means any body or bodies given the legal authority by the Contracting Party to regulate any aspect of the safety of spent fuel or radioactive waste management including the granting of licences;

(1) "reprocessing" means a process or operation, the purpose of which is to extract radioactive isotopes from spent fuel for further use;

(m) "sealed source" means radioactive material that is permanently sealed in a capsule or closely bonded and in a solid form, excluding reactor fuel elements;

(n) "spent fuel" means nuclear fuel that has been irradiated in and permanently removed from a reactor core;

(o) "spent fuel management" means all activities that relate to the handling or storage of spent fuel, excluding off-site transportation. It may also involve discharges;

(p) "spent fuel management facility" means any facility or installation the primary purpose of which is spent fuel management;

(q) "State of destination" means a State to which a transboundary movement is planned or takes place;

(r) "State of origin" means a State from which a transboundary movement is planned to be initiated or is initiated; 
(s) "State of transit" means any State, other than a State of origin or a State of destination, through whose territory a transboundary movement is planned or takes place;

(t) "storage" means the holding of spent fuel or of radioactive waste in a facility that provides for its containment, with the intention of retrieval;

(u) "transboundary movement" means any shipment of spent fuel or of radioactive waste from a State of origin to a State of destination.

\section{ARTICLE 3. SCOPE OF APPLICATION}

1. This Convention shall apply to the safety of spent fuel management when the spent fuel results from the operation of civilian nuclear reactors. Spent fuel held at reprocessing facilities as part of a reprocessing activity is not covered in the scope of this Convention unless the Contracting Party declares reprocessing to be part of spent fuel management.

2. This Convention shall also apply to the safety of radioactive waste management when the radioactive waste results from civilian applications. However, this Convention shall not apply to waste that contains only naturally occurring radioactive materials and that does not originate from the nuclear fuel cycle, unless it constitutes a disused sealed source or it is declared as radioactive waste for the purposes of this Convention by the Contracting Party.

3. This Convention shall not apply to the safety of management of spent fuel or radioactive waste within military or defence programmes, unless declared as spent fuel or radioactive waste for the purposes of this Convention by the Contracting Party. However, this Convention shall apply to the safety of management of spent fuel and radioactive waste from military or defence programmes if and when such materials are transferred permanently to and managed within exclusively civilian programmes.

4. This Convention shall also apply to discharges as provided for in Articles 4, 7, 11, 14, 24 and 26. 


\section{CHAPTER 2 SAFETY OF SPENT FUEL MANAGEMENT}

\section{ARTICLE 4. GENERAL SAFETY REQUIREMENTS}

Each Contracting Party shall take the appropriate steps to ensure that at all stages of spent fuel management, individuals, society and the environment are adequately protected against radiological hazards.

In so doing, each Contracting Party shall take the appropriate steps to:

(i) ensure that criticality and removal of residual heat generated during spent fuel management are adequately addressed;

(ii) ensure that the generation of radioactive waste associated with spent fuel management is kept to the minimum practicable, consistent with the type of fuel cycle policy adopted;

(iii) take into account interdependencies among the different steps in spent fuel management;

(iv) provide for effective protection of individuals, society and the environment, by applying at the national level suitable protective methods as approved by the regulatory body, in the framework of its national legislation which has due regard to internationally endorsed criteria and standards;

(v) take into account the biological, chemical and other hazards that may be associated with spent fuel management;

(vi) strive to avoid actions that impose reasonably predictable impacts on future generations greater than those permitted for the current generation;

(vii) aim to avoid imposing undue burdens on future generations. 


\section{ARTICLE 5. EXISTING FACILITIES}

Each Contracting Party shall take the appropriate steps to review the safety of any spent fuel management facility existing at the time the Convention enters into force for that Contracting Party and to ensure that, if necessary, all reasonably practicable improvements are made to upgrade the safety of such a facility.

\section{ARTICLE 6. SITING OF PROPOSED FACILITIES}

1. Each Contracting Party shall take the appropriate steps to ensure that procedures are established and implemented for a proposed spent fuel management facility:

(i) to evaluate all relevant site-related factors likely to affect the safety of such a facility during its operating lifetime;

(ii) to evaluate the likely safety impact of such a facility on individuals, society and the environment;

(iii) to make information on the safety of such a facility available to members of the public;

(iv) to consult Contracting Parties in the vicinity of such a facility, insofar as they are likely to be affected by that facility, and provide them, upon their request, with general data relating to the facility to enable them to evaluate the likely safety impact of the facility upon their territory.

2. In so doing, each Contracting Party shall take the appropriate steps to ensure that such facilities shall not have unacceptable effects on other Contracting Parties by being sited in accordance with the general safety requirements of Article 4. 


\section{ARTICLE 7. DESIGN AND CONSTRUCTION OF FACILITIES}

Each Contracting Party shall take the appropriate steps to ensure that:

(i) the design and construction of a spent fuel management facility provide for suitable measures to limit possible radiological impacts on individuals, society and the environment, including those from discharges or uncontrolled releases;

(ii) at the design stage, conceptual plans and, as necessary, technical provisions for the decommissioning of a spent fuel management facility are taken into account;

(iii) the technologies incorporated in the design and construction of a spent fuel management facility are supported by experience, testing or analysis.

\section{ARTICLE 8. ASSESSMENT OF SAFETY OF FACILITIES}

Each Contracting Party shall take the appropriate steps to ensure that:

(i) before construction of a spent fuel management facility, a systematic safety assessment and an environmental assessment appropriate to the hazard presented by the facility and covering its operating lifetime shall be carried out;

(ii) before the operation of a spent fuel management facility, updated and detailed versions of the safety assessment and of the environmental assessment shall be prepared when deemed necessary to complement the assessments referred to in paragraph (i).

\section{ARTICLE 9. OPERATION OF FACILITIES}

Each Contracting Party shall take the appropriate steps to ensure that:

(i) the licence to operate a spent fuel management facility is based upon appropriate assessments as specified in Article 8 and is conditional on the completion of a commissioning programme 
demonstrating that the facility, as constructed, is consistent with design and safety requirements;

(ii) operational limits and conditions derived from tests, operational experience and the assessments, as specified in Article 8, are defined and revised as necessary;

(iii) operation, maintenance, monitoring, inspection and testing of a spent fuel management facility are conducted in accordance with established procedures;

(iv) engineering and technical support in all safety-related fields are available throughout the operating lifetime of a spent fuel management facility;

(v) incidents significant to safety are reported in a timely manner by the holder of the licence to the regulatory body;

(vi) programmes to collect and analyse relevant operating experience are established and that the results are acted upon, where appropriate;

(vii) decommissioning plans for a spent fuel management facility are prepared and updated, as necessary, using information obtained during the operating lifetime of that facility, and are reviewed by the regulatory body.

\section{ARTICLE 10. DISPOSAL OF SPENT FUEL}

If, pursuant to its own legislative and regulatory framework, a Contracting Party has designated spent fuel for disposal, the disposal of such spent fuel shall be in accordance with the obligations of Chapter 3 relating to the disposal of radioactive waste. 


\section{CHAPTER 3 SAFETY OF RADIOACTIVE WASTE MANAGEMENT}

\section{ARTICLE 11. GENERAL SAFETY REQUIREMENTS}

Each Contracting Party shall take the appropriate steps to ensure that at all stages of radioactive waste management individuals, society and the environment are adequately protected against radiological and other hazards.

In so doing, each Contracting Party shall take the appropriate steps to:

(i) ensure that criticality and removal of residual heat generated during radioactive waste management are adequately addressed;

(ii) ensure that the generation of radioactive waste is kept to the minimum practicable;

(iii) take into account interdependencies among the different steps in radioactive waste management;

(iv) provide for effective protection of individuals, society and the environment, by applying at the national level suitable protective methods as approved by the regulatory body, in the framework of its national legislation which has due regard to internationally endorsed criteria and standards;

(v) take into account the biological, chemical and other hazards that may be associated with radioactive waste management;

(vi) strive to avoid actions that impose reasonably predictable impacts on future generations greater than those permitted for the current generation;

(vii) aim to avoid imposing undue burdens on future generations. 


\section{ARTICLE 12. EXISTING FACILITIES AND PAST PRACTICES}

Each Contracting Party shall in due course take the appropriate steps to review:

(i) the safety of any radioactive waste management facility existing at the time the Convention enters into force for that Contracting Party and to ensure that, if necessary, all reasonably practicable improvements are made to upgrade the safety of such a facility;

(ii) the results of past practices in order to determine whether any intervention is needed for reasons of radiation protection bearing in mind that the reduction in detriment resulting from the reduction in dose should be sufficient to justify the harm and the costs, including the social costs, of the intervention.

\section{ARTICLE 13. SITING OF PROPOSED FACILITIES}

1. Each Contracting Party shall take the appropriate steps to ensure that procedures are established and implemented for a proposed radioactive waste management facility:

(i) to evaluate all relevant site-related factors likely to affect the safety of such a facility during its operating lifetime as well as that of a disposal facility after closure;

(ii) to evaluate the likely safety impact of such a facility on individuals, society and the environment, taking into account possible evolution of the site conditions of disposal facilities after closure;

(iii) to make information on the safety of such a facility available to members of the public;

(iv) to consult Contracting Parties in the vicinity of such a facility, insofar as they are likely to be affected by that facility, and provide them, upon their request, with 
general data relating to the facility to enable them to evaluate the likely safety impact of the facility upon their territory.

2. In so doing, each Contracting Party shall take the appropriate steps to ensure that such facilities shall not have unacceptable effects on other Contracting Parties by being sited in accordance with the general safety requirements of Article 11.

\section{ARTICLE 14. DESIGN AND CONSTRUCTION OF FACILITIES}

Each Contracting Party shall take the appropriate steps to ensure that:

(i) the design and construction of a radioactive waste management facility provide for suitable measures to limit possible radiological impacts on individuals, society and the environment, including those from discharges or uncontrolled releases;

(ii) at the design stage, conceptual plans and, as necessary, technical provisions for the decommissioning of a radioactive waste management facility other than a disposal facility are taken into account;

(iii) at the design stage, technical provisions for the closure of a disposal facility are prepared;

(iv) the technologies incorporated in the design and construction of a radioactive waste management facility are supported by experience, testing or analysis.

\section{ARTICLE 15. ASSESSMENT OF SAFETY OF FACILITIES}

Each Contracting Party shall take the appropriate steps to ensure that:

(i) before construction of a radioactive waste management facility, a systematic safety assessment and an environmental assessment appropriate to the hazard presented by the facility and covering its operating lifetime shall be carried out; 
(ii) in addition, before construction of a disposal facility, a systematic safety assessment and an environmental assessment for the period following closure shall be carried out and the results evaluated against the criteria established by the regulatory body;

(iii) before the operation of a radioactive waste management facility, updated and detailed versions of the safety assessment and of the environmental assessment shall be prepared when deemed necessary to complement the assessments referred to in paragraph (i).

\section{ARTICLE 16. OPERATION OF FACILITIES}

Each Contracting Party shall take the appropriate steps to ensure that:

(i) the licence to operate a radioactive waste management facility is based upon appropriate assessments as specified in Article 15 and is conditional on the completion of a commissioning programme demonstrating that the facility, as constructed, is consistent with design and safety requirements;

(ii) operational limits and conditions, derived from tests, operational experience and the assessments as specified in Article 15 are defined and revised as necessary;

(iii) operation, maintenance, monitoring, inspection and testing of a radioactive waste management facility are conducted in accordance with established procedures. For a disposal facility the results thus obtained shall be used to verify and to review the validity of assumptions made and to update the assessments as specified in Article 15 for the period after closure;

(iv) engineering and technical support in all safety-related fields are available throughout the operating lifetime of a radioactive waste management facility;

(v) procedures for characterization and segregation of radioactive waste are applied; 
(vi) incidents significant to safety are reported in a timely manner by the holder of the licence to the regulatory body;

(vii) programmes to collect and analyse relevant operating experience are established and that the results are acted upon, where appropriate;

(viii) decommissioning plans for a radioactive waste management facility other than a disposal facility are prepared and updated, as necessary, using information obtained during the operating lifetime of that facility, and are reviewed by the regulatory body;

(ix) plans for the closure of a disposal facility are prepared and updated, as necessary, using information obtained during the operating lifetime of that facility and are reviewed by the regulatory body.

\section{ARTICLE 17. INSTITUTIONAL MEASURES AFTER CLOSURE}

Each Contracting Party shall take the appropriate steps to ensure that after closure of a disposal facility:

(i) records of the location, design and inventory of that facility required by the regulatory body are preserved;

(ii) active or passive institutional controls such as monitoring or access restrictions are carried out, if required; and

(iii) if, during any period of active institutional control, an unplanned release of radioactive materials into the environment is detected, intervention measures are implemented, if necessary. 


\section{CHAPTER 4 GENERAL SAFETY PROVISIONS}

\section{ARTICLE 18. IMPLEMENTING MEASURES}

Each Contracting Party shall take, within the framework of its national law, the legislative, regulatory and administrative measures and other steps necessary for implementing its obligations under this Convention.

\section{ARTICLE 19. LEGISLATIVE AND REGULATORY FRAMEWORK}

1. Each Contracting Party shall establish and maintain a legislative and regulatory framework to govern the safety of spent fuel and radioactive waste management.

2. This legislative and regulatory framework shall provide for:

(i) the establishment of applicable national safety requirements and regulations for radiation safety;

(ii) a system of licensing of spent fuel and radioactive waste management activities;

(iii) a system of prohibition of the operation of a spent fuel or radioactive waste management facility without a licence;

(iv) a system of appropriate institutional control, regulatory inspection and documentation and reporting;

(v) the enforcement of applicable regulations and of the terms of the licences;

(vi) a clear allocation of responsibilities of the bodies involved in the different steps of spent fuel and of radioactive waste management. 
3. When considering whether to regulate radioactive materials as radioactive waste, Contracting Parties shall take due account of the objectives of this Convention.

\section{ARTICLE 20. REGULATORY BODY}

1. Each Contracting Party shall establish or designate a regulatory body entrusted with the implementation of the legislative and regulatory framework referred to in Article 19, and provided with adequate authority, competence and financial and human resources to fulfill its assigned responsibilities.

2. Each Contracting Party, in accordance with its legislative and regulatory framework, shall take the appropriate steps to ensure the effective independence of the regulatory functions from other functions where organizations are involved in both spent fuel or radioactive waste management and in their regulation.

\section{ARTICLE 21. RESPONSIBILITY OF THE LICENCE HOLDER}

1. Each Contracting Party shall ensure that prime responsibility for the safety of spent fuel or radioactive waste management rests with the holder of the relevant licence and shall take the appropriate steps to ensure that each such licence holder meets its responsibility.

2. If there is no such licence holder or other responsible party, the responsibility rests with the Contracting Party which has jurisdiction over the spent fuel or over the radioactive waste.

\section{ARTICLE 22. HUMAN AND FINANCIAL RESOURCES}

Each Contracting Party shall take the appropriate steps to ensure that:

(i) qualified staff are available as needed for safety-related activities during the operating lifetime of a spent fuel and a radioactive waste management facility; 
(ii) adequate financial resources are available to support the safety of facilities for spent fuel and radioactive waste management during their operating lifetime and for decommissioning;

(iii) financial provision is made which will enable the appropriate institutional controls and monitoring arrangements to be continued for the period deemed necessary following the closure of a disposal facility.

\section{ARTICLE 23. QUALITY ASSURANCE}

Each Contracting Party shall take the necessary steps to ensure that appropriate quality assurance programmes concerning the safety of spent fuel and radioactive waste management are established and implemented.

\section{ARTICLE 24. OPERATIONAL RADIATION PROTECTION}

1. Each Contracting Party shall take the appropriate steps to ensure that during the operating lifetime of a spent fuel or radioactive waste management facility:

(i) the radiation exposure of the workers and the public caused by the facility shall be kept as low as reasonably achievable, economic and social factors being taken into account;

(ii) no individual shall be exposed, in normal situations, to radiation doses which exceed national prescriptions for dose limitation which have due regard to internationally endorsed standards on radiation protection; and

(iii) measures are taken to prevent unplanned and uncontrolled releases of radioactive materials into the environment.

2. Each Contracting Party shall take appropriate steps to ensure that discharges shall be limited: 
to keep exposure to radiation as low as reasonably achievable, economic and social factors being taken into account; and

(ii) so that no individual shall be exposed, in normal situations, to radiation doses which exceed national prescriptions for dose limitation which have due regard to internationally endorsed standards on radiation protection.

3. Each Contracting Party shall take appropriate steps to ensure that during the operating lifetime of a regulated nuclear facility, in the event that an unplanned or uncontrolled release of radioactive materials into the environment occurs, appropriate corrective measures are implemented to control the release and mitigate its effects.

\section{ARTICLE 25. EMERGENCY PREPAREDNESS}

1. Each Contracting Party shall ensure that before and during operation of a spent fuel or radioactive waste management facility there are appropriate on-site and, if necessary, off-site emergency plans. Such emergency plans should be tested at an appropriate frequency.

2. Each Contracting Party shall take the appropriate steps for the preparation and testing of emergency plans for its territory insofar as it is likely to be affected in the event of a radiological emergency at a spent fuel or radioactive waste management facility in the vicinity of its territory.

\section{ARTICLE 26. DECOMMISSIONING}

Each Contracting Party shall take the appropriate steps to ensure the safety of decommissioning of a nuclear facility. Such steps shall ensure that:

(i) qualified staff and adequate financial resources are available;

(ii) the provisions of Article 24 with respect to operational radiation protection, discharges and unplanned and uncontrolled releases are applied; 
(iii) the provisions of Article 25 with respect to emergency preparedness are applied; and

(iv) records of information important to decommissioning are kept.

\section{CHAPTER 5 MISCELLANEOUS PROVISIONS}

\section{ARTICLE 27. TRANSBOUNDARY MOVEMENT}

1. Each Contracting Party involved in transboundary movement shall take the appropriate steps to ensure that such movement is undertaken in a manner consistent with the provisions of this Convention and relevant binding international instruments.

In so doing:

(i) a Contracting Party which is a State of origin shall take the appropriate steps to ensure that transboundary movement is authorized and takes place only with the prior notification and consent of the State of destination;

(ii) transboundary movement through States of transit shall be subject to those international obligations which are relevant to the particular modes of transport utilized;

(iii) a Contracting Party which is a State of destination shall consent to a transboundary movement only if it has the administrative and technical capacity, as well as the regulatory structure, needed to manage the spent fuel or the radioactive waste in a manner consistent with this Convention;

(iv) a Contracting Party which is a State of origin shall authorize a transboundary movement only if it can satisfy itself in accordance with the consent of the State of destination that the requirements of subparagraph (iii) are met prior to transboundary movement; 
(v) a Contracting Party which is a State of origin shall take the appropriate steps to permit re-entry into its territory, if a transboundary movement is not or cannot be completed in conformity with this Article, unless an alternative safe arrangement can be made.

2. A Contracting Party shall not licence the shipment of its spent fuel or radioactive waste to a destination south of latitude 60 degrees South for storage or disposal.

3. Nothing in this Convention prejudices or affects:

(i) the exercise, by ships and aircraft of all States, of maritime, river and air navigation rights and freedoms, as provided for in international law;

(ii) rights of a Contracting Party to which radioactive waste is exported for processing to return, or provide for the return of, the radioactive waste and other products after treatment to the State of origin;

(iii) the right of a Contracting Party to export its spent fuel for reprocessing;

(iv) rights of a Contracting Party to which spent fuel is exported for reprocessing to return, or provide for the return of, radioactive waste and other products resulting from reprocessing operations to the State of origin.

\section{ARTICLE 28. DISUSED SEALED SOURCES}

1. Each Contracting Party shall, in the framework of its national law, take the appropriate steps to ensure that the possession, remanufacturing or disposal of disused sealed sources takes place in a safe manner.

2. A Contracting Party shall allow for reentry into its territory of disused sealed sources if, in the framework of its national law, it has accepted that they be returned to a manufacturer qualified to receive and possess the disused sealed sources. 


\section{CHAPTER 6 MEETINGS OF THE CONTRACTING PARTIES}

\section{ARTICLE 29. PREPARATORY MEETING}

1. A preparatory meeting of the Contracting Parties shall be held not later than six months after the date of entry into force of this Convention.

2. At this meeting, the Contracting Parties shall:

(i) determine the date for the first review meeting as referred to in Article 30. This review meeting shall be held as soon as possible, but not later than thirty months after the date of entry into force of this Convention;

(ii) prepare and adopt by consensus Rules of Procedure and Financial Rules;

(iii) establish in particular and in accordance with the Rules of Procedure:

(a) guidelines regarding the form and structure of the national reports to be submitted pursuant to Article 32;

(b) a date for the submission of such reports;

(c) the process for reviewing such reports.

3. Any State or regional organization of an integration or other nature which ratifies, accepts, approves, accedes to or confirms this Convention and for which the Convention is not yet in force, may attend the preparatory meeting as if it were a Party to this Convention.

\section{ARTICLE 30. REVIEW MEETINGS}

1. The Contracting Parties shall hold meetings for the purpose of reviewing the reports submitted pursuant to Article 32. 
2. At each review meeting the Contracting Parties:

(i) shall determine the date for the next such meeting, the interval between review meetings not exceeding three years;

(ii) may review the arrangements established pursuant to paragraph 2 of Article 29, and adopt revisions by consensus unless otherwise provided for in the Rules of Procedure. They may also amend the Rules of Procedure and Financial Rules by consensus.

3. At each review meeting each Contracting Party shall have a reasonable opportunity to discuss the reports submitted by other Contracting Parties and to seek clarification of such reports.

\section{ARTICLE 31. EXTRAORDINARY MEETINGS}

An extraordinary meeting of the Contracting Parties shall be held:

(i) if so agreed by a majority of the Contracting Parties present and voting at a meeting; or

(ii) at the written request of a Contracting Party, within six months of this request having been communicated to the Contracting Parties and notification having been received by the secretariat referred to in Article 37 that the request has been supported by a majority of the Contracting Parties.

\section{ARTICLE 32. REPORTING}

1. In accordance with the provisions of Article 30, each Contracting Party shall submit a national report to each review meeting of Contracting Parties. This report shall address the measures taken to implement each of the obligations of the Convention. For each Contracting Party the report shall also address its: 
(i) spent fuel management policy;

(ii) spent fuel management practices;

(iii) radioactive waste management policy;

(iv) radioactive waste management practices;

(v) criteria used to define and categorize radioactive waste.

2. This report shall also include:

(i) a list of the spent fuel management facilities subject to this Convention, their location, main purpose and essential features;

(ii) an inventory of spent fuel that is subject to this Convention and that is being held in storage and of that which has been disposed of. This inventory shall contain a description of the material and, if available, give information on its mass and its total activity;

(iii) a list of the radioactive waste management facilities subject to this Convention, their location, main purpose and essential features;

(iv) an inventory of radioactive waste that is subject to this Convention that:

(a) is being held in storage at radioactive waste management and nuclear fuel cycle facilities;

(b) has been disposed of; or

(c) has resulted from past practices.

This inventory shall contain a description of the material and other appropriate information available, such as volume or mass, activity and specific radionuclides;

(v) a list of nuclear facilities in the process of being decommissioned and the status of decommissioning activities at those facilities. 


\section{ARTICLE 33. ATTENDANCE}

1. Each Contracting Party shall attend meetings of the Contracting Parties and be represented at such meetings by one delegate, and by such alternates, experts and advisers as it deems necessary.

2. The Contracting Parties may invite, by consensus, any intergovernmental organization which is competent in respect of matters governed by this Convention to attend, as an observer, any meeting, or specific sessions thereof. Observers shall be required to accept in writing, and in advance, the provisions of Article 36.

\section{ARTICLE 34. SUMMARY REPORTS}

The Contracting Parties shall adopt, by consensus, and make available to the public a document addressing issues discussed and conclusions reached during meetings of the Contracting Parties.

\section{ARTICLE 35. LANGUAGES}

1. The languages of meetings of the Contracting Parties shall be Arabic, Chinese, English, French, Russian and Spanish unless otherwise provided in the Rules of Procedure.

2. Reports submitted pursuant to Article 32 shall be prepared in the national language of the submitting Contracting Party or in a single designated language to be agreed in the Rules of Procedure. Should the report be submitted in a national language other than the designated language, a translation of the report into the designated language shall be provided by the Contracting Party.

3. Notwithstanding the provisions of paragraph 2, the secretariat, if compensated, will assume the translation of reports submitted in any other language of the meeting into the designated language. 


\section{ARTICLE 36. CONFIDENTIALITY}

1. The provisions of this Convention shall not affect the rights and obligations of the Contracting Parties under their laws to protect information from disclosure. For the purposes of this article, "information" includes, inter alia, information relating to national security or to the physical protection of nuclear materials, information protected by intellectual property rights or by industrial or commercial confidentiality, and personal data.

2. When, in the context of this Convention, a Contracting Party provides information identified by it as protected as described in paragraph 1 , such information shall be used only for the purposes for which it has been provided and its confidentiality shall be respected.

3. With respect to information relating to spent fuel or radioactive waste falling within the scope of this Convention by virtue of paragraph 3 of Article 3, the provisions of this Convention shall not affect the exclusive discretion of the Contracting Party concerned to decide:

(i) whether such information is classified or otherwise controlled to preclude release;

(ii) whether to provide information referred to in sub-paragraph (i) above in the context of the Convention; and

(iii) what conditions of confidentiality are attached to such information if it is provided in the context of this Convention.

4. The content of the debates during the reviewing of the national reports at each review meeting held pursuant to Article 30 shall be confidential. 


\section{ARTICLE 37. SECRETARIAT}

1. The International Atomic Energy Agency, (hereinafter referred to as "the Agency") shall provide the secretariat for the meetings of the Contracting Parties.

2. The secretariat shall:

(i) convene, prepare and service the meetings of the Contracting Parties referred to in Articles 29, 30 and 31;

(ii) transmit to the Contracting Parties information received or prepared in accordance with the provisions of this Convention.

The costs incurred by the Agency in carrying out the functions referred to in sub-paragraphs (i) and (ii) above shall be borne by the Agency as part of its regular budget.

3. The Contracting Parties may, by consensus, request the Agency to provide other services in support of meetings of the Contracting Parties. The Agency may provide such services if they can be undertaken within its programme and regular budget. Should this not be possible, the Agency may provide such services if voluntary funding is provided from another source.

\section{CHAPTER 7. FINAL CLAUSES AND OTHER PROVISIONS}

\section{ARTICLE 38. RESOLUTION OF DISAGREEMENTS}

In the event of a disagreement between two or more Contracting Parties concerning the interpretation or application of this Convention, the Contracting Parties shall consult within the framework of a meeting of the Contracting Parties with a view to resolving the disagreement. In the event that the consultations prove unproductive, recourse can be made to the mediation, conciliation and arbitration mechanisms provided for in international law, including the rules and practices prevailing within the IAEA. 


\section{ARTICLE 39. SIGNATURE, RATIFICATION, ACCEPTANCE, APPROVAL, ACCESSION}

1. This Convention shall be open for signature by all States at the Headquarters of the Agency in Vienna from 29 September 1997 until its entry into force.

2. This Convention is subject to ratification, acceptance or approval by the signatory States.

3. After its entry into force, this Convention shall be open for accession by all States.

4. (i) This Convention shall be open for signature subject to confirmation, or accession by regional organizations of an integration or other nature, provided that any such organization is constituted by sovereign States and has competence in respect of the negotiation, conclusion and application of international agreements in matters covered by this Convention.

(ii) In matters within their competence, such organizations shall, on their own behalf, exercise the rights and fulfil the responsibilities which this Convention attributes to States Parties.

(iii) When becoming party to this Convention, such an organization shall communicate to the Depositary referred to in Article 43, a declaration indicating which States are members thereof, which Articles of this Convention apply to it, and the extent of its competence in the field covered by those articles.

(iv) Such an organization shall not hold any vote additional to those of its Member States.

5. Instruments of ratification, acceptance, approval, accession or confirmation shall be deposited with the Depositary. 


\section{ARTICLE 40. ENTRY INTO FORCE}

1. This Convention shall enter into force on the ninetieth day after the date of deposit with the Depositary of the twenty-fifth instrument of ratification, acceptance or approval, including the instruments of fifteen States each having an operational nuclear power plant.

2. For each State or regional organization of an integration or other nature which ratifies, accepts, approves, accedes to or confirms this Convention after the date of deposit of the last instrument required to satisfy the conditions set forth in paragraph 1, this Convention shall enter into force on the ninetieth day after the date of deposit with the Depositary of the appropriate instrument by such a State or organization.

\section{ARTICLE 41. AMENDMENTS TO THE CONVENTION}

1. Any Contracting Party may propose an amendment to this Convention. Proposed amendments shall be considered at a review meeting or at an extraordinary meeting.

2. The text of any proposed amendment and the reasons for it shall be provided to the Depositary who shall communicate the proposal to the Contracting Parties at least ninety days before the meeting for which it is submitted for consideration. Any comments received on such a proposal shall be circulated by the Depositary to the Contracting Parties.

3. The Contracting Parties shall decide after consideration of the proposed amendment whether to adopt it by consensus, or, in the absence of consensus, to submit it to a Diplomatic Conference. A decision to submit a proposed amendment to a Diplomatic Conference shall require a two-thirds majority vote of the Contracting Parties present and voting at the meeting, provided that at least one half of the Contracting Parties are present at the time of voting.

4. The Diplomatic Conference to consider and adopt amendments to this Convention shall be convened by the Depositary and held no later than one year after the appropriate decision taken in accordance with paragraph 3 of this article. The Diplomatic Conference shall make every effort to 
ensure amendments are adopted by consensus. Should this not be possible, amendments shall be adopted with a two-thirds majority of all Contracting Parties.

5. Amendments to this Convention adopted pursuant to paragraphs 3 and 4 above shall be subject to ratification, acceptance, approval, or confirmation by the Contracting Parties and shall enter into force for those Contracting Parties which have ratified, accepted, approved or confirmed them on the ninetieth day after the receipt by the Depositary of the relevant instruments of at least two thirds of the Contracting Parties. For a Contracting Party which subsequently ratifies, accepts, approves or confirms the said amendments, the amendments will enter into force on the ninetieth day after that Contracting Party has deposited its relevant instrument.

\section{ARTICLE 42. DENUNCIATION}

1. Any Contracting Party may denounce this Convention by written notification to the Depositary.

2. Denunciation shall take effect one year following the date of the receipt of the notification by the Depositary, or on such later date as may be specified in the notification.

\section{ARTICLE 43. DEPOSITARY}

1. The Director General of the Agency shall be the Depositary of this Convention.

2. The Depositary shall inform the Contracting Parties of:

(i) the signature of this Convention and of the deposit of instruments of ratification, acceptance, approval, accession or confirmation in accordance with Article 39;

(ii) the date on which the Convention enters into force, in accordance with Article 40; 
(iii) the notifications of denunciation of the Convention and the date thereof, made in accordance with Article 42;

(iv) the proposed amendments to this Convention submitted by Contracting Parties, the amendments adopted by the relevant Diplomatic Conference or by the meeting of the Contracting Parties, and the date of entry into force of the said amendments, in accordance with Article 41.

\section{ARTICLE 44. AUTHENTIC TEXTS}

The original of this Convention of which the Arabic, Chinese, English, French, Russian and Spanish texts are equally authentic, shall be deposited with the Depositary, who shall send certified copies thereof to the Contracting Parties.

\section{IN WITNESS WHEREOF THE UNDERSIGNED, BEING DULY AUTHORIZED TO THAT EFFECT, HAVE SIGNED THIS CONVENTION.}

Done at Vienna on the fifth day of September, one thousand nine hundred and ninety-seven. 